УДК 550.8.052

ОСНОВНЫЕ ВОПРОСЫ ИССЛЕДОВАНИЙ НАУЧНОЙ ШКОЛЫ «ЭНЕРГОРЕСУРСОСБЕРЕГАЮЩИЕ ТЕХНОЛОГИИ БУРЕНИЯ, РАЗРАБОТКИ И ЭКСПЛУАТАЦИИ МЕСТОРОЖДЕНИЙ УГЛЕВОДОРОДОВ»

В ОБЛАСТИ НЕФТЕГАЗОВОЙ ПРОМЫШЛЕННОСТИ

\title{
THE MAIN RESEARCH ISSUES OF THE SCIENTIFIC SCHOOL «ENERGY-RESOURCE-SAVING TECHNOLOGIES OF DRILLING, DEVELOPMENT AND OPERATION OF HYDROCARBON FIELDS» IN OIL AND GAS INDUSTRY
}

Котенев Ю.А., Аюпова Е.Н., Файрузова Л.А.

Уфимский государственный нефтяной технический университет, г. Уфа, Российская Федерация

Yu.A. Kotenev, E.N. Ayupova, L.A. Fairuzova

Ufa State Petroleum Technological University, Ufa, Russian Federation e-mail: fayruzova.liana.ru

Аннотация. В статье представлены основные вопросы исследований научной школы в области геологии, бурения и разработки. Показана и исследована научная деятельность основоположников научной школы энергоресурсосберегающих технологий: А.И. Спивака, М.Р. Мавлютова, В.М. Девликамова, 3.А. Хабибуллина, Л.А. Алексеева, Н.Ш. Хайрединова, Б.М. Орлинского, И.Л. Мархасина, И.Г. Пермякова, а также их приемников и научных соратников. Рассмотрены основные научные достижения коллективов ученых. Описаны результаты работ по различным научноисследовательским направлениям, и показана эффективность внедрения 
новых технологий. Показана роль научной школы в процессах совершенствования нефтегазовых технологий. Описан процесс модернизации в системе добычи и разработки нефти и газа, а также качественного улучшения технологического процесса.

Представлена корреляция работы научной школы с образовательным процессом. Затрагивается проблема, связанная с замедлением развития потенциала современных научных школ. Показаны результаты анализа деятельности научных школ, повлиявшей на процесс подготовки квалифицированных кадров. На основе системного анализа показана взаимосвязь образовавшихся научных школ с последующей интеграцией научных идей в образовательное пространство с целью подготовки квалифицированных кадров. Приведена количественная зависимость квалифицированных выпускников научной школы в повышении техникоэкономических показателей нефтегазодобывающих компаний.

Abstract. The article presents the main research questions of the scientific school in the field of geology, drilling and development. The school founders scientific activity involved in energy-resource-saving technologies is presented and studied by: A.I. Spivak, M.R. Mavlyutov, V.M. Devlikamov, Z.A. Khabibullin, L.A. Alekseeva, N.Sh. Khairedinov, B.M Orlinsky, I.L. Marhasin, I.G. Permyakov. The researches of these scientists' successors and colleagues are also revealed. The main scientific achievements of school' groups are considered. The results of works on various scientific and research areas are described in the article; the new technologies efficiency is shown. The scientific school role in the processes of improving oil and gas technologies is presented. The oil and gas production upgrading the system and development process, as well as technological process qualitative improvement are covered.

In this article, the interaction between the work of the scientific school and the educational process is stated. The problem connected with the recession of the modern scientific schools development is paid attention to. The results of analyzing the scientific schools activity that influenced the training qualified 
specialists process are shown. In this article, according to the systematic analysis, the interrelationship between the established scientific schools is given; and the subsequent integration of scientific ideas into the educational environment in order to train qualified experts is considered. The scientific school qualified graduates quantitative interdependence with increasing the technical and economic indices of oil and gas producing companies is presented.

Ключевые слова: наука, исследования, кафедра, школа, разработка, трудноизвлекаемые запасы, месторождение, нефтеотдача, продуктивность.

Keywords: science, research, department, school, development, hard-torecover reserves, field, oil recovery factor, producibility.

Сохранение и развитие научной школы - это механизм для оптимизации образовательной системы в целом. Развитие научных школ напрямую детерминирует всю стратегию дальнейшего образования и подготовки специализированных кадров.

В 1968 г. была основана научная школа, основоположниками которой стали: А.И. Спивак, М.Р. Мавлютов, В.М. Девликамов, З.А. Хабибуллин, Л.А. Алексеев, Н.Ш. Хайрединов, Б.М. Орлинский, И.Л. Мархасин, И.Г. Пермяков.

Основные направления научных исследований коллектива:

1. геолого-технологическое обоснование технологий разработки месторождений углеводородов;

2. разработка буровых и тампонажных растворов, породоразрушающих и специальных инструментов с применением наноматериалов и нанотехнологий;

3. разработка и эксплуатация месторождений с неньютоновскими нефтями;

4. разработка и эксплуатация нефтяных месторождений в осложненных условиях; 
5. оценка надежности, прогнозирования ресурса, разработка диагностических методов и средств для определения технического состояния нефтепромыслового и бурового оборудования.

Основные научные результаты коллектива:

1. Применение дезинтеграторной технологии при получении порошкообразных материалов для строительства скважин / Б.С. Измухамбетов, Ф.А. Агзамов, Б.Т. Умралиев. СПб.: ООО «Недра», 2007;

2. Сбор, подготовка и хранение нефти и газа. Технологии и оборудование / Р.С. Сулейманов, А.Р. Хафизов, В.В. Шайдаков, В.В. Чеботарев, В.А. Ставицкий, О.П. Кабанов;

3. Аномальные нефти / В.В. Девликамиов, 3.А. Хабибуллин, М.М. Кабиров. М.: Недра, 1975;

4. Теоретические основы надежности буровых и нефтепромысловых машин / Е.И. Ишемгужин. Уфа: УНИ, 1981;

5. Ремонт бурового и нефтепромыслового оборудования / Е.И. Ишемгужин. Уфа: УНИ, 1986;

6. Обеспечение надежности нефтепромыслового оборудования / Е.И. Ишемгужин и др. Уфа: Монография, 2008;

7. Инновационные направления в решении проблем эффективной разработки небольших карбонатных залежей нефти за счет энергосберегающих технологий на примере Мальцевского и Некрасовского месторождений мелекесской депрессии / В.С. Тимиров, Р.Р. Хузин, В.Е. Андреев // VIII Конгресс нефтегазопромышленников России. Секция А «Проблемы ресурсои энергосбережения в технологиях освоения трудноизвлекаемых запасов углеводородов» (Уфа, 26 мая 2009 г.). Уфа: Монография, 2009; 
8. Метатехнология системного анализа разработки нефтяных месторождений с различными категориями трудноизвлекаемых запасов / Ш.Х. Султанов. Уфа: Монография, 2009. 204 с.;

9. Прогнозирование применения методов увеличения нефтеотдачи для крупных нефтегазоносных территорий / Н.Ш. Хайрединов, К.М. Федоров, В.Е. Андреев, Ю.А. Котенев. Уфа: Гилем, 1997. 106 с.;

10. Премия Правительства Российской Федерации за разработку и промышленное внедрение высокоэффективных технологий и забойных технических средств для бурения и освоения скважин (Постановление Правительства Российской Федерации № 175 от 29.12.2000 г.). Присвоено звание «Лауреат премии Правительства Российской Федерации в области науки и техники» проф. М.Р. Мавлютову (руководитель работы), проф. Л.А. Алексееву, проф. Г.Г. Ишбаеву, проф. Г.В. Конесеву, проф. А.И. Спиваку, доц. Б.Н. Трушкину.

Безусловно, научные исследования специалистов в области нефтегазового дела коррелируют с развитием нефтяной геологии, разработки месторождений нефти и газа, бурения.

Общие научные исследования, которые велись командой, были следующими:

1. геолого-технологическое обоснование технологий разработки месторождений углеводородов;

2. разработка буровых и тампонажных растворов, породоразрушающих и специальных инструментов с применением наноматериалов и нанотехнологий;

3. разработка и эксплуатация месторождений с неньютоновскими нефтями;

4. разработка и эксплуатация нефтяных месторождений в осложненных условиях; 
5. оценка надежности, прогнозирование ресурса, разработка диагностических методов и средств для определения технического состояния нефтепромыслового и бурового оборудования.

Одной из лидирующих фигур в становлении научной школы «Энергоресурсосберегающие технологии бурения, разработки и эксплуатации месторождений углеводородов» был Спивак Александр Иванович. Заслуженный научный деятель БАССР, заслуженный научный деятель РСФСР, почетный нефтяник СССР, лауреат премии Правительства Российской Федерации в области науки и техники. Он занимался исследования в области абразивности горных пород, абразивного изнашивания буровых инструментов и механизмов разрушения горных пород для нефтяной промышленности. На основе своих исследований А.И. Спивак разработал фундаментальные механизмы разрушения горных пород с применением различных инденторов. На месторождениях применяли различные по физико-химическому составу присадки к промывочным жидкостям, которые обеспечивали охлаждающее и смазывающее действие при бурении. Эти научные исследования явились основой в области бурения нефтяных скважин [1].

А.И. Спивак - первый выпускник вуза и в последующем его ректор (1976-1994 гг.). Доктор технических наук, профессор, автор более 250 публикаций, среди которых 22 учебника, 43 изобретений и монографий. Став ректором, А.И. Спивак достиг высоких успехов в укреплении материальной и социальной базы университета (ранее института). Активно развивал научно-производственную деятельность Уфимского нефтяного института (УНИ), в том числе формирование договорных отношений с предприятиями, и, конечно, по привлечению в университет опытных нефтяников для обучения новых кадров.

В разных областях страны были подписаны договоры с нефтедобывающими, нефтеперерабатывающими и нефтехимическими 
предприятиями. Активно открывались учебные кафедры с привлечением квалифицированных специалистов. Это послужило становлению и развитию новой научной школы под названием «Энергоресурсосбрегающие технологии бурения, разработки и эксплуатации месторождений углеводородов». Были сформированы со специальной направленностью советы по защите кандидатских и докторских диссертаций, что расширило развитие научной работы и возможности повышения квалификации преподавательского состава.

В 1950 г. кафедру «Бурение» УНИ закончил Мидхат Рахматуллич Мавлютов и в этом же году, будучи аспирантом Московского нефтяного института, начал внедрять науку в педагогическую работу. В 1963 г. получил звание профессора, а годом позже стал заведующим кафедрой «Бурения», где и проработал до 1998 г. В эти годы на кафедре увеличился объем научно-исследовательских работ, стали выполняться фундаментальные поисковые исследования академического характера в области разрушения пород, износа породоразрушающего инструмента, гидравлики промывки скважин. Под руководством Мидхата Рахматуллича в преподавательском составе кафедры появились следующие сотрудники: Л.А. Алексеев, Н.П. Матюшин, Л.М. Левинсон, Н.М. Филимонов, А.Н. Попов, К.И. Вдовин, М.Ш. Акмуллин, Г.В. Конесев, Р.Х. Санников, Ю.В. Крючков, А.Ф. Старков, Р.М. Нургалеев, Т.О. Акбулатов. С учетом накопленного опыта и материала были изданы учебники для вузов, с помощью которых обучалось не одно поколение специалистов. Достижения в науке позволили открыть диссертационный совет по данной специальности по защите кандидатских, а далее и докторских работ.

В своих трудах и статьях А.Н. Петров, Г.В. Конесев, И.Н. Давыдова, М.М. Акодис приводили результаты исследований смазочных добавок и применения их на месторождениях Западной Сибири, это - реагенты хорошего качества с отсутствием нежелательных химикатов, состоящие из органических веществ ствола хвойного дерева. Каждые новые добавки 
проверялись опытным путем в конкретных горно-геологических условиях, где они используются. Лабораторные исследования на скважинах в глинистом растворе показали незначительные снижение уровня $\mathrm{pH}$ и снижение напряжения сдвига (поверхностного натяжения), происходит уменьшение липкости глинистой корки [2].

Ф.А. Агзамов уделял внимания вопросам применения тампонажного материала. Установлено, что не всегда достаточно высокое качество цементирования обсадных колонн является следствием применения тампонажных материалов для крепления скважин. Повышение качества закачивания скважин может быть выполнено специальным цементом даже при невыполнении ряда технологических мероприятий. С помощью специального цемента решается герметичность контактных зон цементного камня, долговечность крепи скважин и т.д. Практика показала, что на буровой специального цемента не сделать. При смешивании базового цемента с модифицированными компонентами не получается высококачественный цемент из-за плохой гомогенизации томпонажной смеси. Следует отметить, что ввод любых добавок ведет к снижению прочности цементного камня, а также известно, что модифицирующие вещества проявляют свою активность при высоких температурах [3]. Из-за тампонажных цементов было принято решение о применении дезинтеграторной технологии. При исследовании было доказано, что дезинтеграторы обладают преимуществом над другими номинально смесительными машинами.

В дезинтеграторе при обработке твердых неорганических материалов с увеличением удельной поверхности протекает механохимические реакции, в результате которых происходит качественное изменение (разрушение кристаллов при сопровождении электрических микрозарядов, а также эмиссии электронов). Изменяются химические и физические свойства, вызывающие увеличение реакционной способности и изменение растворимости. Обработка тампонажными средствами 
(с модифицирующими добавками и без) показала, что режим обработки влияет на все участвующие материалы. Дезинтеграторная обработка повышает седиментационную устойчивость. В то же время водоотдача уменьшается в два раза. После обработки процесс структурообразования идет гораздо интенсивнее. Растет чисто контактов и скорость коагуляционной составляющей, повышается прочность камня на 30-70 \% при изгибе, на 30-90 \% при сжатии. Эффект активизации максимален при затвердевании камня. В нормальных условиях технология приготовления облегченного тампонажного материала оказывает существенное влияние на структурные характеристики камня.

В монографиях Н.А. Петров, Г.В. Конесев, И.Н. Давыдова и В.Г. Султанов приводили результаты по изучению повышения качества первичного и вторичного вскрытия нефтяных пластов. На лангепасской группе месторождений описаны геолого-технические условия бурения и эксплуатации скважин нефтегазового региона. Даны рекомендации по выбору конструкций забоев скважин. Проверены результаты лабораторных, стендовых и промысловых исследований совместимости пластовых флюидов и технологических растворов [4].

Леонид Александрович Алексеев начал работать на кафедре бурения нефтяных и газовых скважин в 1960 г. Пройдя весь путь от ассистента до доктора технических наук, профессора и декана горно-нефтяного факультета, он совмещал педагогическую и научную работу. Под его авторством более 20 учебно-методических пособий, 12 авторских свидетельств и патентов, более 120 статей и выступлений на научных конференциях. При участии Алексеева разработаны породоразрушающие и фрезерные инструменты для бурения и ремонта скважин. Леонид Александрович впервые оценил температурный режим работы породоразрушающих инструментов, обосновал направления по его регулированию и учету с целью повышения долговечности, производительности инструментов и эффективности использования 
энергии. Легко влившись в коллектив, он стал активно развивать научную школу нефтяников.

Прибывшие с производства на кафедру новые сотрудники Л.М. Левинсон, Т.О. Акбулатов, Х.И. Акчурин активно влились в учебный процесс по подготовке молодых специалистов-нефтяников. В нефтяной промышленности было много открытых вопросов, связанных с управлением процессами при искривлении скважин, изучение которых явилось большим шагом вперед. Л.М. Левинсоном, Т.О. Акбулатовым, Х.И. Акчуриным рассмотрены механизм и профилактика самопроизвольного искривления скважин, а также приборы навигации, позволяющие контролировать все координаты в стволе скважин. Изучены и применены новые способы и компоновки инструмента для бурения направленных скважин. Рассмотрены вопросы выброса шлама из горизонтальных скважин с изучением экологической составляющей [5-7].

Важный раздел обеспечения надежности нефтегазовых объектов в нефтяной промышленности изучен Е.И. Ишемгужиным. Надежность машин зависит от: технологий изготовления, совершенства конструкции, а также от условий работы. Она определяется выполнением заданных функций, сохраняя начальные эксплуатационные показатели в течение требуемого времени. Уровень, определяющий надежность машины, - это долговечность, безотказность, ремонтопригодность и сохраняемость. Все показатели машины зависят от конструкции и специфики еe функционитрования. Основное понятие надежности - отказ или нарушение работоспособности объекта, поэтому при изучении надежности Е.И. Ишемгужиным использованы методы вероятности и математической статистики. Особенностью объектов нефтяной промышленности является сложность конструкций и меняющиеся режимы работы. С отказами машин связаны материальные потери и угроза безопасности работников. Необходимо постоянное усовершенствование технологий и конструкций 
машин. Это, безусловно, важная проблема, которую решала научная школа во благо нефтяной промышленности [5].

5 сентября 1964 г. ректором УНИ В.Е. Губиным подписан приказ № 256 об объединении кафедр «Общая геология» и «Разведка нефтяных и газовых месторождений» в одну общую кафедру под названием «Геология и разведка нефтяных и газовых месторождений». У штурвала нового сплоченного объединенного коллектива встал доцент Сергей Александрович Позднышев.

А.С. Позднышев приложил немало сил для того, чтобы дисциплины «Промысловая геология» и «Динамическая геология» равноценно вошли в состав учебного плана горных специальностей. Свое основное предназначение кафедра видела в развитии интереса и понимания необходимости изучения горных пород при бурении разреза и вскрытии нефтяных пластов. В 1969-1973 гг. бразды правления штурвалом научного судна перешли к кандидату геолого-минералогических наук Шевкунову Евгению Никитовичу. С его именем связано пополнение учебного плана дисциплинами геофизической направленности: «Полевая геофизика», «Геофизические исследования скважин» и другие. Создается учебная лаборатория с наглядными геофизическими приборами и необходимым оборудованием для производства каротажных работ в процессе бурения скважин. Это дает огромную возможность для вклада геологической составляющей в научную школу, образовавшуюся в 1968 г.

На кафедре сложился и продолжал трудиться долгие годы сплоченный коллектив, основой которого были: Е.Н. Шевкунов, Э.Л. Ревенко, И.Г. Пермяков, А.Э. Алкснэ, М.А. Токарев, К.С. Березина, Т.А. Дроздова, Е.М. Выгодский, А.П. Корешенкова, Д.В. Рахимкулова, С.Г. Шебалина.

Работник кафедры и производства, талантливый ученый Илья Григорьевич Пермяков активно занимался научной деятельностью и положил начало крупным проектам по Казанковскому и Манчаровскому нефтяным месторождениям Башкирии, проекты продолжились и по 
месторождениям, находящимся в Западной Сибири. Им разработаны кардинально новые методы анализа во время разработки и предложены быстрые расчетные методы уровня добываемой нефти и воды при составлении технологических схем. Экспресс-методы И.Г. Пермякова были применены для пересчета добычи нефти и воды восточной группы Прикамских месторождений. Учитывались в проекте доразработки крупного Мухановского месторождения нефти. Расчетные технологические показатели разработки применяются еще на 27 месторождениях в Западной Сибири. Производится оценка ожидаемого эффекта добавки поверхностно-активных веществ в закачиваемую воду и заводнения нефтяной залежи. Написанное им учебное пособие «Нефтегазопромысловая геология и геофизика» на сегодняшний день является фундаментальным трудом и широко используются в научных исследованиях молодых аспирантов [6].

Проводились фундаментальные работы по изучению в области нефтяной геологии на Юго-Западе. В 1998 г. Н.Ш. Хайрединов, Ю.А. Котенев, В.Р. Мерздяков, В.Е. Андреев, А.А. Носачев занимались изучением геолого-геофизических характеристик и основных месторождений Юго-Запада Башкортостана, а также анализировали структуры запасов залежей. Проводилась характеристика и анализ текущего состояния разработки и эффективности нескольких способов, применяемых для повышения нефтеотдачи. Были произведены группирования объектов разработки, где разработали самые подходящие и доступные методы нефтеотдачи в зависимости от геологии того или иного района. В своих работах ученые дают рекомендации по доразработке объектов с использованием современных технологий увеличения нефтеотдачи пластов. Они занимаются аспектами анализа геологотехнологической разработки и прогнозирования применения методов увеличения нефтеотдачи (МУН) на многих месторождениях Башкирии. Это обуславливалось необходимостью изыскать новые пути стабилизации 
добычи нефти и снизить обводненность добываемой продукции, тем самым увеличив рост трудноизвлекаемых запасов. В зависимости от геологической залежи, ее структуры, процесс извлечения нефти из пластов требовал нестандартных подходов. Перед каждой большой работой ставилась цель - на основе уточнения геолого-геофизических условий месторождения дальнейшая работа по извлечению нефти. Проводился анализ состояния разработки и структуры запасов, обобщались данные по применению МУН для месторождений. Выделенные группы дифференцировались для доразработки по усовершенствованным технологиям, и продолжалось движение дальше, в глубь недр.

Работая в ГАНУ «Институт нефтегазовых технологий и новых материалов Республики Башкортостан», проблемами геологических ресурсов по поискам, добычи и освоению нефти занимался Хайрединов Нил Шахиджанович. Рецензентами научно-методических трудов Нила Шахиджановича Хайрединова были такие старейшие специалисты по геологии, как профессор И.Г. Пермяков, доктор геолого-минералогических наук В.М. Юсупов и другие. Н.Ш. Хайрединовым изучены геологические условия и формы скопления залежей нефти и газа в недрах Земли, закономерности размещения нефтяных и газовых месторождений, также условий их возникновения, преобразования и разрушения. Он занимался важными проблемами по выбору мест заложения первых поисковых скважин для вскрытия углеводородных залежей; оконтуриванием обнаруженной залежи для максимальной добычи природного ресурса.

Доктору геолого-минералогических наук, заместителю директора по научной работе Научно-исследовательского института по повышению нефтеотдачи пластов Академии наук РБ Хайретдинову Нилу Шахиджановичу было присвоено почетное звание «Заслуженный деятель науки Республики Башкортостан». Он является Отличником нефтяной промышленности СССР, лауреатом Премий имени академиков 
А.А. Трофимука, В.И. Муравленко, Минвуза СССР, а также является заслуженным деятелем науки Республики Башкирии.

Н.Ш. Хайрединов в 1973 г. становится заведующим геологической кафедрой. На новой должности он много сил отдает обучению молодых кадров и кафедральному развитию. На кафедре он продолжает развивать тесные договорные отношения с компаниями ПО «Башнефть», БашНИПИнефть, Институтом геологии БФАН СССР. По совместительству, кафедре помогают в образовательном процессе квалифицированные сотрудники с производства. Проблема освоения карбонатных коллекторов и разработка новых технологий добычи волновала многих.

В образовательной деятельности Нил Шахиджанович обучал будущие кадры геологическим азам промыслового инженера: знания об условиях залегания нефти, о пластовых толщах, о процессах, происходящих в пластах при эксплуатации залежей, об источниках пластовой энергии, их изменении во времени и в пространстве. Полагал, что после открытия залежей квалифицированный инженер-геолог нефти и газа должен владеть навыками определения запасов нефти и газа (промышленных запасов). Это залежи, которые можно извлечь из пласта, при этом разработка которых должна быть экономически целесообразной.

Благодаря усилиям Нила Шахиджановича, с 1985 г. кафедра «Геология и разведка нефтяных и газовых месторождений» приобретает права выпускающей кафедры по специальности «Геология нефти и газа». Начинается активная научная подготовка горных инженеров-геологов. Промышленности для поисков наращивания добычи остро требуются специалисты-геологи для нефтегазодобывающих управлений, для управлений буровыми работами, научно-исследовательских институтов и многочисленных структурных подразделений нефтегазодобывающих предприятий. Для подготовки специалистов по направлению «Нефтепромысловая геология» на кафедру был приглашен доктор геолого- 
минералогических наук, профессор Сагди Ахмадиевич Султанов, ранее работавший заместителем директора по науке в научно-исследовательском институте «ТатНИПИнефть». Его научные идеи легли в основу применения ядерной геофизики и контроля за разработкой нефтяных залежей в нефтяной промышленности СССР. За внедрение высокоинформативных импульсных нейронных методов для повышения эффективности поисков и разведки нефтяных и газовых месторождений С. А. Султанов был дважды удостоен премии им. И.М. Губкина и звания лауреата Государственной премии СССР.

Под руководством Н.Ш. Хайрединова на кафедре «Геология и разведка нефтяных и газовых месторождений» в эти года был подготовлен ряд аспирантов и соискателей. Многие выпускники кафедры «Разработка нефтегазовых месторождений» прошли геологическую школу совершенствования, а также освоили методику анализа разработки нефтяных месторождений. Защитили диссертации и перешли на преподавательскую работу: О.В. Пешкин, В.Е. Андреев, В.Г. Щербинин, Ю.А. Котенев, К.М. Рогачев, В.Ш. Мухаметшин, В.И. Васильев, В.Г. Салимов, А.А. Шамсуаров и другие.

Приемником и научным соратником Н.Ш. Хайрединова стал закончивший в 1983 г. горно-нефтяной факультет, а через 6 лет и аспирантуру Ю.А. Котенев. Он успешно защитил кандидатскую диссертацию по геолого-минералогическим наукам в 1991 г. С 2004 г. является доктором технических наук, профессором. Научные доклады представлены на конгрессах и симпозиумах различного уровня в России и за рубежом. Им были опубликованы более 300 научных публикаций, из которых 13 монографий. Ю.А. Котеневым подготовлено свыше 70 проектных, а также научно-исследовательских работ по геологическим вопросам, вопросам разведки и разработки нефтяных месторождений в разных точках страны и не только. В область изучения попали месторождения Башкирии, Татарстана, Западной Сибири, Казахстана, 
Краснодарского края, Оренбургской области, Перу и Норвегии. Оригинальность предложенными научными открытиями подтверждена патентами РФ, что является выдающимся вкладом для развития научной школы.

Им исследованы и написаны фундаментальные труды и проделана огромная работа в области геологии и разработки нефтяных и газовых месторождений, в области геологического обоснования технологий интенсификации добычи и увеличения нефтеотдачи на месторождениях с трудноизвлекаемыми и остаточными запасами нефти. На основе геологоматематического и геолого-статистического моделирования выполняет обоснование системного воздействия на различные категории остаточных запасов нефти и газа. Исследования в данной области создают реальную основу для разработки и внедрения новых адресных технологий по освоению трудноизвлекаемых углеводородов. С научными коллегами А.П. Чижовым, К.М. Федоровым, В.Е. Андреевым и Р.Р. Хузиным изучены проблемы в области совершенствования соляно-кислотного воздействия на карбонатные коллекторы с прогнозируемым результатом. В научных работах совместно с профессором В.Е. Андреевым и профессором Ш.Х. Султановым исследованы вопросы по метатехнологиям регулирования разработки нефтяных месторождений с различными категориями трудноизвлекаемых запасов. Также рассматриваются важные нефтяные геологические аспекты в изучении геолого-физических характеристик продуктивных пластов и свойств флюидов по нефтяным месторождениям юга Башкирии. Исследуются вопросы по оцениванию обстановки текущего состояния разработки залежей с применением современных методов нефтеотдачи. На одном из старейших нефтегазовых полигонов НГДУ «Ишимбайнефь» проводится крупная научная работа по обоснованию системного воздействия на различные категории трудноизвлекаемых запасов на основе геолого-математического моделирования. Этот научный системный опыт, безусловно, является 
важной научной составляющей в условиях постоянного совершенствования применяемых технологий для повышения нефтеотдачи.

С 2007 г. на кафедре «Геология и разведка нефтяных и газовых месторождений» начаты новые перемены. Под руководством заведующего кафедрой Ю.А. Котенева начинают функционировать лаборатории геологического и гидродинамического моделирования залежей нефти и газа. Реконструируется геологический музей с образцами горных пород и минералов. Оборудование кафедры пополняется новыми мощными и современными микроскопами для детального изучения каменного материала будущими геологами. Параллельно развивается и мультимедийная оснащенность лабораторных и лекционных аудиторий кафедры. Лаборатории оснащаются компьютерными тренажерами от ведущих мировых компаний для создания геолого-гидродинамических моделей нефтяных и газовых залежей нефти и газа. Для наглядности учебной информации применяются мультимедийные проекторы с экранами, средства визуализации изображений в микроскопах с выводом на экран, стендовые витрины с наглядным горным геологическим материалом, фотоаппаратура для получения микроскопических снимков горных пород, а также коллекции шлифов со многих месторождений Башкирии и России. Это все, безусловно, качественно улучшает понимание и восприятие геологического обучения будущими специалистами.

Создана кафедральная геофильмотека, она включает более 50 фильмов и сюжетов об истории планеты Земля, геологических процессах, проходящих внутри земли и на ее поверхности, а также фильмы об исторической составляющей развития кафедры и университета в целом. Для анализа текущей обстановки обучающимся необходимо знать исторические истоки образования геологической науки, кафедры, университета и окружающего мира. Этот процесс работает по 
инверсионному принципу актуализма, который требует при любых реконструкциях событий и явлений, имевших место в прошлом, исходить из того, что они происходили по тем же законам и принципам, по которым происходят нынешние. В формулировке Лайеля принцип звучит так: «Настоящее есть ключ к прошлому». Следование принципу актуализма позволяет моделировать ныне не существующие объекты и системы, изучать их строение и функционирование, формируя картину прошлого и получая таким образом возможность прослеживать закономерности развития мира [3].

Открывается новое направление по обучению кадровых магистрантов «Геолого-геофизические проблемы освоения нефти и газа» для освоения новых программных ресурсов в рамках «Нанотехнология в России». Идет постоянное привлечение молодых специалистов на кафедру для возможности передачи базовых навыков формирования геологических основ. Активно готовятся молодые научные исследователи и аспиранты. Юрий Алексеевич подготовил 15 кандидатов геолого-минералогических и технических наук.

С 1983 г. специальность «Геофизические методы исследования скважин» является одной из профилирующих специальностей во всех нефтегазовых вузах и также была открыта в нашем университете. В 1985 г. была организована кафедра геофизики под руководством профессора Орлинского Бориса Михайловича (1933-2006 гг.). Доктор геологоминералогических наук Б.М. Орлинский являлся ведущим специалистом в области контроля за разработкой залежей нефти. В 1957 г. окончил геолого-разведочный факультет Грозненского нефтяного института. Докторская диссертация на тему «Контроль за разработкой многопластовых залежей нефти геофизическими методами» защищена в 1979 г. в МИНХ. Свою жизнь Орлинский Борис Михайлович отдал науке. Под его авторством более 75 публикационных работ, им написано 2 монографии, открыто 14 изобретений. В Волго-Уральском филиале (ВУФ) 
ВНИИгеофизика (г. Октябрьский) Б.М. Орлинский занимался разработкой и внедрением новой геофизической аппаратуры для исследования нефтяных скважин. Знание тонкостей и физических основ радиоактивного каротажа помогли Б.М. Орлинскому развивать научные идеи в данном направлении. Внедрение методики обсадки продуктивных пластов стеклопластиковыми хвостовиками получила широкое распространение на месторождениях в Мангышлаке, Западной Сибири, Удмуртии. Научные труды по технологии насыщения прискваженной зоны перед цементированием скважины борсодержащими продуктами востребованы по сей день. Под его непосредственным научным руководством разрабатывались многие идеи технологии геофизических исследований скважин для их капитального ремонта.

Борис Михайлович подготовил 7 кандидатов наук, награжден пятью медалями ВДНХ, лауреат Уральской горной премии. В 1988 г. состоялся первый выпуск горных инженеров-геофизиков. В отличие от родственных кафедр других вузов здесь большое внимание уделяется подготовке специалистов в области геофизических методов исследования и контроля за разработкой нефтяных месторождений. Это направление дало возможность будущим кадрам успешно работать как в геофизических, так и на нефтедобывающих предприятиях. С момента образования кафедры полноценной учебной структурой, участвующей в подготовке специалистов, были созданы филиалы кафедры. Орлинский взаимодействовал с квалифицированными сотрудниками таких организаций, как ПО «Башнефтегеофизика», ПО «Башкиргеология», ВНИИнефтепромгеофизика, которые безоговорочно помогали развиваться научной геофизической школе в области образования. Благодаря ВНИИнефтепромгеофизика в учебных лабораториях кафедры появилась радиотехническая аппаратура. ПО «Башнефтегеофизика» оснастила учебные лаборатории специальной полевой и промысловой геофизической аппаратурой, а также персональными ЭВМ. 
В 1995 г. открыта аспирантура, в которой могли продолжить образование выпускники, проявившие склонность и способность к научным исследованиям.

В 1954 г. московскую аспирантуру с последующей защитой кандидатской диссертации закончил Владимир Владимирович Девликамов.

В 1972 г. В.В. Девликамов активно занялся вопросами разработки нефтяных месторождений с применением заводнения пласта. Исследуемый принцип заключается в закачке огромного количества воды в пласт с содержанием значительного количества кислорода. Кислород расходуется из воды от нагнетательных скважин до эксплуатационных. Исследования проводились в 1969 г. на девонских отложениях Туймазинского нефтяного месторождения и девонских отложениях Шкаповского месторождения. Хроматографическим исследованием выявляли содержание углеводорода от легких до тяжелых. Таким образом, определяли состав и свойства нефти. Аналогичным методом исследования нефти проводились в отложениях нижнего карбона Манчаровского и отложений девона Сергеевского месторождений. После многочисленных опытов окисления нефти кислородом, закаченным в пласт в растворенном виде и перемешанным с нефтью, результаты показали увеличение асфальтенов в пласте на 10-15\%. Выяснилось, что кислород с нефтью в больших количествах реагирует быстро. На вязкость и плотность растворенный кислород не повлиял.

В 1973 г. ученым рассматривался вопрос о влиянии активных веществ на структурно-механические свойства нефти. В.В. Девликамов разработал способы улучшения показателей разработки нефтяных месторождений при ослаблении структурно-механических свойств нефти. Он проводил опыты c применением поверхностно-активных веществ с последующим установлением равновесного состояния нефти и водного раствора, а также необходимых концентраций веществ. 
Одним из важных вопросов является выявленный закон о фильтрации неньютоновских нефтей в пористой среде. При помощи повышения точности замеров, наиболее подходящих к реальным условиям, В.В. Девликамов выявил модель закона фильтрации данных нефтей. Проводил опытные исследования коэффициента подвижности неньютоновских нефтей для расчета фильтрации через пористую среду. На базе экспериментальных исследований были построены кривые зависимости объема скорости фильтрации от градиента давления на Арланском нефтяном месторождении. Основная модель фильтрации была составлена на основе многочисленных опытов на месторождениях Башкортостана и Татарстана. В настоящее время построенная модель дает возможность проводить точные численные расчеты на практике [8].

И.Л. Мархасин. Важным аспектом исследования Ильи Львовича были вопросы по решению задач, связанных с разработкой нефтяных месторождений с последующим увеличением продуктивности скважин. В 1961 г. большая часть работы проводилась на карбонатных отложениях Арланского месторождения в Башкирии. Проводились исследования, показывающие влияния асфальто-смолистых компонентов нефти на ее фильтрацию. Влияние концентрации компонентов на фильтрацию прослеживается при различных проницаемостях песка и абсорбционной составляющей. Проделанные опыты помогают решать технологические задачи при разработке карбонатных залежей, которые характеризуются высоким содержанием смолистых веществ в нефти.

Плеяда ученых: У.М. Байков, Н.К. Крупнов, И.Л. Мархасин, Г.А. Бабалян, Л.А. Пелевин и другие рассматривали проблему о возможности закачки вод на забое нагнетательных скважин, содержащих механические примеси. Осуществлялись мероприятия по оценке осадков смеси соленого состава отличного от пластового. Велись опыты по изучению влияния осадков на проницаемость пород. При исследовании 
пород установлено, что влияние осадкообразования на проницаемость пород минимально.

С целью рационального использования природных ресурсов И.Л. Мархасиным подробно изучена данная проблема, решены вопросы использования водных ресурсов и их охраны от загрязнений.

\section{Выводы}

Впервые детально исследован вопрос образования научных школ и вклад их основоположников: А.И. Спивака, М.Р. Мавлютова, В.М. Девликамова, 3.А. Хабибуллина, Л.А. Алексеева, Н.Ш. Хайрединова, Б.М. Орлинского, И.Л. Мархасина, И.Г. Пермякова. Исследованы основные научные направления и показана их роль в передаче научноинформативной составляющей будущим инженерно-технических работникам.

На основе системного анализа установлена взаимосвязь образовавшихся научных школ с последующей интеграцией научных идей в образовательное пространство с целью подготовки квалифицированных кадров. Приведена качественная зависимость квалифицированных выпускников научных школ в повышении технико-экономических показателей нефтегазодобывающих компаний.

3. Показана роль научной школы «Энергоресурсосберегающие технологии бурения, разработки и эксплуатации месторождений углеводородов» в процессах совершенствования нефтегазовых технологий, модернизации систем добычи и разработки нефти и газа, а также в качественной эффективности технологических процессов. 


\section{Список используемых источников}

1. Сыртланов А.Ш., Сафонов Е.Н., Самойлов Е.Н. и др. Башкирских нефтяников славные имена (биографические данные). Уфа: РИЦ АНК «Башнефть», 1997. 647 с.

2. Петров Н.А., Конесев Г.В., Давыдова И.Н., Акодис М.М. Применение смазочной добавки K-LUBE в буровых растворах // Электронный научный журнал «Нефтегазовое дело». 2007. № 2. URL: http://ogbus.ru/authors/PetrovNA/PetrovNA_13.pdf.

3. Каримов Н.Х., Агзамов Ф.А., Газизов Х.В., Каримов И.Н., Комлева С.Ф. Облегченный тампонажный раствор с улучшенными технологическими свойствами // Известия ВУЗов. Нефть и газ. 1997. № 6. C. 45 .

4. Петров Н.А., Давыдова И.Н., Комлева С.Ф. Уменьшение плотности цементного раствора поверхностно-активными веществами // Актуальные проблемы нефтегазового дела: сб. науч. тр.: в 4 т. Уфа: Изд-во УГНТУ, 2006. T. 2. C. $97-100$.

5. Ишемгужин И.Е., Атнагулов А.Р., Зотов А.Н., Ишемгужин Е.И. Специальные критерии согласия для малой выборки при оценке надежности нефтепромыслового оборудования // Электронный научный журнал «Нефтегазовое дело». 2008. № 2. URL: http://ogbus.ru/authors/IshemguzhinIE/IshemguzhinIE_1.pdf.

6. Пермяков И.Г. Экспресс-метод расчета технологических показателей разработки нефтяных месторождений. М.: Недра, 1975. 128 с.

7. Акбулатов Т.О., Акчурин Х.И., Левинсон Л.М., Самигуллин В.Х. Информационное обеспечение процесса бурения. Уфа, 2013. 55 с.

8. Девликамов В.В., Хабибуллин 3.А., Кабиров М.М. Аномальные нефти. М.: Недра, 1975. 168 с. 


\section{References}

1. Syrtlanov A.Sh., Safonov E.N., Samoilov E.N. e.a. Bashkirskikh neftyanikov slavnye imena (biograficheskie dannye) [Glorious Names of Bashkirian Oilmen (Biographical Data)]. Ufa, RITs ANK «Bashneft'», 1997. 647 p. [in Russian].

2. Petrov N.A., Konesev G.V., Davydova I.N., Akodis M.M. Primenenie smazochnoi dobavki K-LUBE $\mathrm{v}$ burovykh rastvorakh [Application of K-LUBE Lubricant in Drilling Fluids]. Elektronnyi nauchnyi zhurnal «Neftegazovoe delo»Electronic Scientific Journal «Oil and Gas Business», 2007, No. 2. URL: http://ogbus.ru/authors/PetrovNA/PetrovNA_13.pdf. [in Russian].

3. Karimov N.Kh., Agzamov F.A., Gazizov Kh.V., Karimov I.N., Komleva S.F. Oblegchennyi tamponazhnyi rastvor s uluchshennymi tekhnologicheskimi svoistvami [Lightweight Oil-Well Slurry with Improved Technological Properties]. Izvestiya vuzov. Neft' $i$ gaz - Izvestiya of Higher Institutions. Oil and Gas, 1997, No. 6, pp. 45. [in Russian].

4. Petrov H.A., Davydova I.N., Komleva S.F. Umen'shenie plotnosti tsementnogo rastvora poverkhnostno-aktivnymi veshchestvami [Decrease in the Density of Cement Mortar Surface-Active Substances]. Sbornik nauchnykh trudov «Aktual'nye problemy neftegazovogo dela»: v 4 t. [Collection of Scientific Works «Actual Problems of Oil and Gas Business»: in 4 Vol. Ufa, UGNTU Publ., 2006, Vol. 2, pp. 97-100. [in Russian].

5. Ishemguzhin I.E., Atnagulov A.R., Zotov A.N., Ishemguzhin E.I. Spetsial'nye kriterii soglasiya dlya maloi vyborki pri otsenke nadezhnosti neftepromyslovogo oborudovaniya [Specific Consent Criteria for a Small Sample in Assessing the Reliability of Oilfield Equipment]. Elektronnyi nauchnyi zhurnal «Neftegazovoe delo» - Electronic Scientific Journal «Oil and Gas Business», 2008, No. 2. URL: http://ogbus.ru/authors/IshemguzhinIE/IshemguzhinIE_1.pdf. [in Russian]. 
6. Permyakov I.G. Ekspress-metod rascheta tekhnologicheskikh pokazatelei razrabotki neftyanykh mestorozhdenii [Express-Method of Calculation of Technological Indicators of Development of Oil Deposits]. Moscow, Nedra Publ., 1975. 128 p. [in Russian].

7. Akbulatov T.O., Akchurin Kh.I., Levinson L.M., Samigullin V.Kh. Informatsionnoe obespechenie protsessa bureniya [Information Support of the Drilling Process]. Ufa, 2013. 55 p. [in Russian].

8. Devlikamov V.V., Khabibullin Z.A., Kabirov M.M. Anomal'nye nefti [Abnormal Oils]. Moscow, Nedra Publ., 1975. 168 p. [in Russian].

\section{Сведения об авторах}

\section{About the authors}

Котенев Ю.А., д-р техн. наук, профессор, заведующий кафедрой «Геология и разведка нефтяных и газовых месторождений», ФГБОУ ВО «УГНТУ», г. Уфа, Российская Федерация

Yu.A. Kotenev, Doctor of Engineering Sciences, Professor of Geology and Exploration of Oil and Gas Fields Department, FSBEI HE «USPTU», Ufa, Russian Federation

Аюпова Е.Н., старший преподаватель кафедры «Геология и разведка нефтяных и газовых месторождений», ФГБОУ ВО «УГНТУ», г. Уфа, Российская Федерация

E.N. Ayupova, Senior Lecturer of Geology and Exploration of Oil and Gas Fields Department, FSBEI HE «USPTU», Ufa, Russian Federation

Файрузова Л.А., студент кафедры «Геология и разведка нефтяных и газовых месторождений», ФГБОУ ВО «УГНТУ», г. Уфа, Российская Федерация

L.A. Fairuzova, Student of of Geology and Exploration of Oil and Gas Fields Department, FSBEI HE «USPTU», Ufa, Russian Federation

e-mail: fayruzova.liana.ru 